\title{
High Rates of Nitrogen Change Composition of Shortgrass Rangeland in Southeastern Wyoming
}

\section{FRANK RAUZI}

Highlight: High rates of nitrogen applied at one time or over a 4-year period markedly changed the botanical composition of shortgrass range. Blue grama and buffalograss cover declined and western wheatgrass increased. Total yields were significantly increased, largely because of the increase of annual forbs. Thus the only desirable change in the composition resulting from the high $\mathrm{N}$ application was the increase of western wheatgrass. Over the 5-year period, the $\mathrm{NO}_{3}-\mathrm{N}$ accumulated in the 12- to 24-inch soil depth, whereas the grass roots were concentrated in the top foot of soil. The high rates of $\mathbf{N}$ increased crude protein significantly, thereby enhancing the palatability of the forage. Forbs on the high $\mathbf{N}$ plots were searched out and readily grazed by the sheep. Crude protein content was higher in the forbs than in the grasses in the fall. I his study shows that high $\mathrm{N}$ rates applied either at one time or in yearly applications are neither economical nor practical because of the shift in the composition to undesirable annual forbs and slow recovery by the perennial grasses. The 150-lb N/acre rate applied once might be considered more practical than the other rates used in this study. Over the 5-year period this $\mathrm{N}$ rate produced $1,705 \mathrm{lb}$ more total herbage than the check or $11.4 \mathrm{lb}$ of herbage/lb of $N$. Neither the yield nor the crude protein increase was large enough to justify nitrogen fertilization of this range as an economic practice.

Forage production on rangeland is largely determined by the plant-soilrange condition and climate. Nitrogen (N) fertilization increases herbage production on some sites. A review of the literature by Lorenz and Rogler (1973) indicated that single applications of less than $30 \mathrm{lb} \mathrm{N} /$ acre did not significantly increase dry matter production, but that rates greater than $60 \mathrm{lb} /$ acre usually did. Ford and Siddoway (1971) found that initial applications of 100 to $200 \mathrm{lb}$ $\mathrm{N} /$ acre were required for the native range sites studied in northeastern Montana to reach their maximum productivity.

However, $\mathrm{N}$ fertilization can change the botanical composition of rangelands. Rauzi et al. (1968) found that with above-average precipitation, forbs and annual grasses accounted for more than $40 \%$ of the total herbage on plots fertilized with 33 and $66 \mathrm{lb}$ N/acre 2

The author is soil scientist, U.S. Department of Agriculture, Agricultural Research Service, Water Conservation on Range and Disturbed Lands, University of Wyoming, Laramie 82070 .

The research is a contribution from the Agr. Res. Serv. U.S. Dep. Agr., in cooperation with the Wyoming Experiment Station. JA 911.

Manuscript received August 16, 1977. and 3 years after application in southeastern Wyoming. On a mixed prairic type range in Alberta, Canada, the composition of the vegetation was markedly changed by the application of 772 or $975 \mathrm{lb} /$ acre. Death of some native species from the high $\mathrm{N}$ rates resulted in bare ground that was invaded by weedy species (Johnston et al. 1967). Hyder and Bement (1972) also found that annual forb populations increased as a result of fertilization of shortgrass plains of northcentral Colorado. Russian thistle (Salsola kali) and slim leaf goosefoot (Chenopodium leptophyllum) increased after foliar application of urea on shortgrass range in northcentral Colorado (Houston and Van Der Sluijs 1973). Dwyer (1971) found that the production of forbs was not significantly affected by the addition of $40 \mathrm{lb} \mathrm{N} /$ acre in southcentral New Mexico. Houston and Hyder (1975) stated that high rates of $\mathrm{N}$ (191,403, and $604 \mathrm{lb} /$ acre) decreased the density of some desirable plants and increased that of several undesirable ones.

Applications of high rates of $\mathrm{N}(600$ to $1,000 \mathrm{lb} \mathrm{N} / \mathrm{acre}$ ) on rangelands were first investigated by Johnston et al. (1967) and Choriki et al. (1968). These rates affected the composition drastically: annual forbs increased and perennial grasses decreased. Also, some forbs concentrated nitrate to toxic levels.

Power (1970) found that application of $480 \mathrm{lb} \mathrm{N} /$ acre immediately established a large pool of $\mathrm{NO}_{3}-\mathrm{N}$ in the soil. Most of the fertilizer not used in one season was carried over in mineral form to the next season. Thus Power (1970) concluded that most fertilizer applied in excess of that required by the vegetation under semiarid conditions remains in the root zone until it is absorbed by the roots and translocated to new growth. The $\mathrm{N}$-immobilizing capacity of a given system may vary somewhat with soil texture, vegetation, and other parameters (Power 1972).

This paper discusses the effects of high rates of $\mathrm{N}$ fertilization of shortgrass rangeland, loamy range site in southeastern Wyoming. High $\mathrm{N}$ rates are considered as more than $100 \mathrm{lb}$ per acre and low rates, as $100 \mathrm{lb}$ or less per acre.

\section{Methods}

The study area was in southeastern Wyoming at the Archer Substation about 10 miles east of Cheyenne. The elevation is about $6,100 \mathrm{ft}$. The dominant species are blue grama (Bouteloua gracilis), buffalograss (Buchloe dactyloides), and western wheatgrass (Agropyron smithii). Annual grasses and forbs were present in varying amounts. Soil on the experimental area was Archerson fine sandy loam, a member of the mixed, mesic family of Aridic Argiustolls. Archerson soils are on nearly level to gently sloping fans and terraces of granitic origin containing Arkosic sand and gravel and are noncalcareous to 24 inches and calcareous from 24 to 60 inches. Texture, $\mathrm{pH}$, organic matter content and sodium-bicarbonate-extractable phospho- 
rus for the 0 - to 6-inch and 6-to 12 -inch soil depth, were respectively loam, $6.3,2.7 \%$ and $16 \mathrm{lb} /$ acre and sandy clay loam, 6.9, $1.7 \%$ and $4 \mathrm{lb} /$ acre.

In March 1970 , plots 10 by $50 \mathrm{ft}$ were established on native rangeland. The experimental design was a randomized complete block with four treatments and three reapplications. Ammonium-nitrate was applied once at rates of 0,150 , and 600 lb N/acre and a fourth treatment of $150 \mathrm{lb}$ $\mathrm{N} /$ acre applied annually for 4 years. All fertilizer was applied in March with a 5-ft spreader.

Each spring (1970 through 1974) three subplots $4 \mathrm{ft}^{2}$ ( 14.3 by 40.3 inches) were randomly located in each plot, and the previous year's vegetation was removed before plant growth started. Herbage in the subplots was harvested at ground level in mid-August or early September by major species. Annual grasses, forbs, and Sandberg bluegrass matured earlier and a large part of this production was lost before harvest. After the subplots were harvested, the experimental area was grazed by sheep.

Air-dry herbage yields were determined for the major grass species, dryland sedges, and total herbage. Herbage yields were statistically analyzed and Duncan's multiple range test for significance was applied at the $5 \%$ probability level. Botanical composition was determined by weight.

Each fall (1970 through 1974) four soil cores $4.20 \mathrm{~cm}$ in diameter were obtained from the 0- to 6-inch and 6- to 12-inch depths from each plot. The soil cores were oven dried at $105^{\circ} \mathrm{C}$ for 48 hours, and the soil was then washed from the root biomass. All organic material that floated and root material werc collected and thoroughly washed, oven dried at $70^{\circ} \mathrm{C}$ for 24 hours, weighed, and analyzed for total N.

The plant and root material of the major species was ground in a Wiley mill to pass 40-mesh openings. Total plant $\mathrm{N}$ was determined by the Kjeldahl method and crude protein was calculated (\% $\mathrm{N}$ by 6.25$)$.

Three soil samples each from the 0- to 6-, 6- to 12-, and 12- to 24-inch depths were obtained in April and again in late August or early September to determine soil water content. In September 1974 three soil samples were obtained from the 0- to 6-, 6to 12-, 12- to 24-, and 24-to 36-inch depths from all main plots and open dried at $55^{\circ} \mathrm{C}$ for 15 hours. These soil samples were analyzed for $\mathrm{NO}_{3}-\mathrm{N}$ using a $\mathrm{NO}_{3}$-specific ion electrode.

\section{Results and Discussion}

\section{Herbage Yields}

Yields of major grass species, total grass plus sedges, and total herbage varied with years and treatments (Table 1). Nitrogen treatments significantly increased the average 5-year yields (1970-1974) of western wheatgrass and blue grama. However, the average yield for blue grama is misleading because yields declined dramatically the last 3 years of the study, particularly on plots receiving $600 \mathrm{lb}$ N/acre in one application. Average mean yields of buffalograss were significantly reduced by the $\mathrm{N}$ treatments, whereas those of dryland sedges were not

Table 1. Yields (lb/acre) of western wheatgrass, blue grama, buffalograss, dryland sedges, total grass, and total herbage from fertilized and nonfertilized shortgrass rangeland. Archer Substation, Cheyenne, Wyo., 1970-1974.

\begin{tabular}{|c|c|c|c|c|c|}
\hline Year & Check & $\begin{array}{c}150 \mathrm{lb} \\
\mathrm{N} / \text { acre }^{1}\end{array}$ & $\begin{array}{c}150 \mathrm{lb} \\
\mathrm{N} / \mathrm{acre}^{2} \\
4 \text {-years }\end{array}$ & $\begin{array}{c}600 \mathrm{lb} \\
\mathrm{N} / \mathrm{acre}^{\mathrm{l}}\end{array}$ & $\begin{array}{l}\text { Year } \\
\text { mean }\end{array}$ \\
\hline \multicolumn{5}{|c|}{ Western wheatgrass } & , \\
\hline 1970 & $62^{a}$ & $132^{a}$ & $166^{a}$ & $148^{a}$ & $127^{a 3}$ \\
\hline 1971 & $85^{c}$ & $318^{a b}$ & $177^{a b c}$ & $370^{a}$ & $237^{a}$ \\
\hline 1972 & $31^{a}$ & $83^{a}$ & $142^{a}$ & $165^{a}$ & $105^{a}$ \\
\hline 1973 & $76^{c}$ & $175^{b}$ & $171^{b c}$ & $408^{x}$ & $208^{a}$ \\
\hline 1974 & $113^{a}$ & $198^{a}$ & $218^{a}$ & $204^{a}$ & $183^{a}$ \\
\hline Mean & $73^{c}$ & $181^{b}$ & $175^{b}$ & $259^{a}$ & \\
\hline \multicolumn{6}{|c|}{ Blue grama } \\
\hline 1970 & $349^{b}$ & $721^{a b}$ & $577^{a b}$ & $739^{a}$ & $596^{a}$ \\
\hline 1971 & $309^{c}$ & $394^{b c}$ & $473^{b}$ & $630^{a}$ & $451^{b}$ \\
\hline 1972 & $308^{b}$ & $361^{a}$ & $390^{a}$ & $271^{a}$ & $332^{b}$ \\
\hline 1973 & $365^{a}$ & $469^{a}$ & $580^{a}$ & $389^{a}$ & $451^{b}$ \\
\hline 1974 & $381^{a}$ & $329^{a}$ & $218^{a}$ & $99^{b}$ & $257^{c}$ \\
\hline Mean & $342^{b}$ & $455^{a}$ & $448^{a}$ & $426^{a}$ & \\
\hline \multicolumn{6}{|c|}{ Buffalograss } \\
\hline 1970 & $90^{a}$ & $85^{a}$ & $111^{a}$ & $66^{a}$ & $88^{a}$ \\
\hline 1971 & $182^{a}$ & $124^{a}$ & $92^{a}$ & $76^{a}$ & $118^{a}$ \\
\hline 1972 & 103 & 34 & 22 & 24 & $46^{b}$ \\
\hline 1973 & $171^{a}$ & $138^{a}$ & $36^{a}$ & $8^{a}$ & $88^{a}$ \\
\hline 1974 & 147 & 82 & 2 & 5 & $59^{a}$ \\
\hline Mean & $139^{a}$ & $93^{b}$ & $53^{c}$ & $36^{c}$ & \\
\hline \multicolumn{6}{|c|}{ Dryland sedges } \\
\hline 1970 & $58^{a}$ & $80^{a}$ & $74^{a}$ & $74^{a}$ & $71^{a}$ \\
\hline 1971 & $68^{a}$ & $95^{a}$ & $126^{a}$ & $110^{a}$ & $100^{a}$ \\
\hline 1972 & $45^{a}$ & $95^{a}$ & $122^{a}$ & $80^{a}$ & $85^{a}$ \\
\hline 1973 & $97^{a}$ & $141^{a}$ & $72^{a}$ & $111^{a}$ & $105^{a}$ \\
\hline 1974 & $77^{a}$ & $101^{a}$ & $77^{a}$ & $84^{a}$ & $85^{a}$ \\
\hline Mean & $69^{a}$ & $102^{a}$ & $94^{a}$ & $92^{a}$ & \\
\hline \multicolumn{6}{|c|}{ Total grass and sedges } \\
\hline 1970 & $560^{b}$ & $1020^{a}$ & $932^{a b}$ & $1028^{a}$ & $885^{a}$ \\
\hline 1971 & $647^{c}$ & $1022^{a b}$ & $896^{b c}$ & $1240^{a}$ & $951^{a}$ \\
\hline 1972 & $492^{a}$ & $575^{a}$ & $670^{a}$ & $468^{a}$ & $551^{c}$ \\
\hline 1973 & $711^{a}$ & $926^{a}$ & $806^{a}$ & $915^{a}$ & $839^{b}$ \\
\hline 1974 & $735^{a}$ & $764^{a}$ & $559^{a}$ & $393^{a}$ & $613^{c}$ \\
\hline Mean & $629^{c}$ & $861^{a}$ & $773^{b}$ & $809^{a b}$ & \\
\hline \multicolumn{6}{|c|}{ Forbs } \\
\hline 1970 & $15^{a}$ & $25^{a}$ & $60^{a}$ & $63^{a}$ & $41^{d}$ \\
\hline 1971 & $10^{a}$ & $80^{a}$ & $20^{a}$ & $297^{a}$ & $102^{c}$ \\
\hline 1972 & $11^{c}$ & $53^{c}$ & $265^{b}$ & $507^{a}$ & $209^{b}$ \\
\hline 1973 & $10^{c}$ & $96^{c}$ & $587^{b}$ & $889^{a}$ & $395^{a}$ \\
\hline 1974 & $43^{b}$ & $97^{b}$ & $362^{a}$ & $320^{a}$ & $205^{b}$ \\
\hline Mean & $18^{c}$ & $70^{c}$ & $259^{b}$ & $415^{a}$ & \\
\hline \multicolumn{6}{|c|}{ Total herbage } \\
\hline 1970 & $575^{b}$ & $1280^{a}$ & $970^{a b}$ & $1090^{a}$ & $979^{b}$ \\
\hline 1971 & $658^{c}$ & $1102^{b}$ & $961^{b}$ & $1537^{a}$ & $1064^{b}$ \\
\hline 1972 & $503^{c}$ & $648^{b}$ & $936^{a b}$ & $1065^{a}$ & $788^{c}$ \\
\hline 1973 & $718^{d}$ & $1044^{c}$ & $1695^{a b}$ & $1841^{a}$ & $1324^{a}$ \\
\hline 1974 & $778^{a}$ & $860^{a}$ & $921^{a}$ & $713^{a}$ & $818^{c}$ \\
\hline Mean & $646^{c}$ & $987^{b}$ & $1097^{a b}$ & $1249^{a}$ & \\
\hline
\end{tabular}

${ }^{1}$ Nitrogen applied once in March 1970.

${ }^{2}$ Nitrogen applied at the rate of $150 \mathrm{lb} /$ acre in March 1970, 1971, 1972, and 1973.

${ }^{3}$ Means within columns among treatments and years with the same letters are not significantly different at the $5 \%$ level according to Duncan's multiple range test. affected. Total grass plus sedges yield and total herbage yield were both significantly increased by $\mathrm{N}$ treatments. Yields of total grass and sedges declined the last 3 years of the study on all $\mathrm{N}$ treatments. In 1972, 1973, and 1974, annual forbs accounted for nearly half of the total herbage on the treatment that received $600 \mathrm{lb} \mathrm{N} /$ acre and less than $3 \%$ of the total herbage on check plots. 
The decline in blue grama and buffalograss and the increase in annual grasses and forbs may be related to the dry, open winter in 1971 and 1972 coupled with high winds that dried the surface soil. Reduction of the grass density left a void filled by annual forbs, particularly slim leaf goosefoot and field penpycress (Thalapsis arvense). In 1972, 1973, and 1974, plots treated with either $600 \mathrm{lb} \mathrm{N} /$ acre applied once or $150 \mathrm{lb} \mathrm{N} /$ acre applied each year for 4 years had a solid stand of either slim leaf goosefoot or field pennycress. During the first 2 years of
Check

150 1bs N/acre one time

$-x-x-x-x-x-150$ lbs N/acre each year for 4 -years

-........- 600 1bs N/acre one time
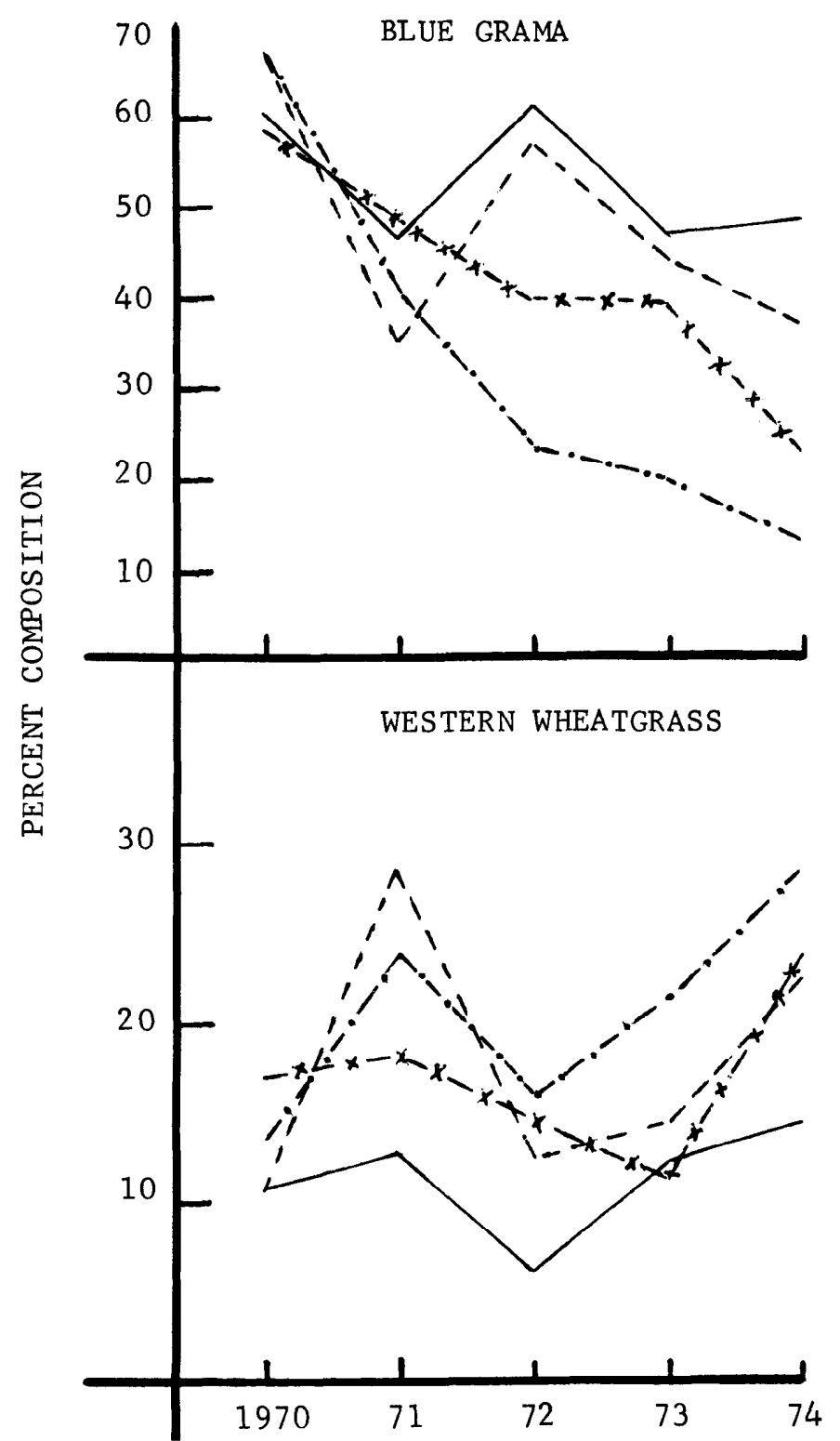
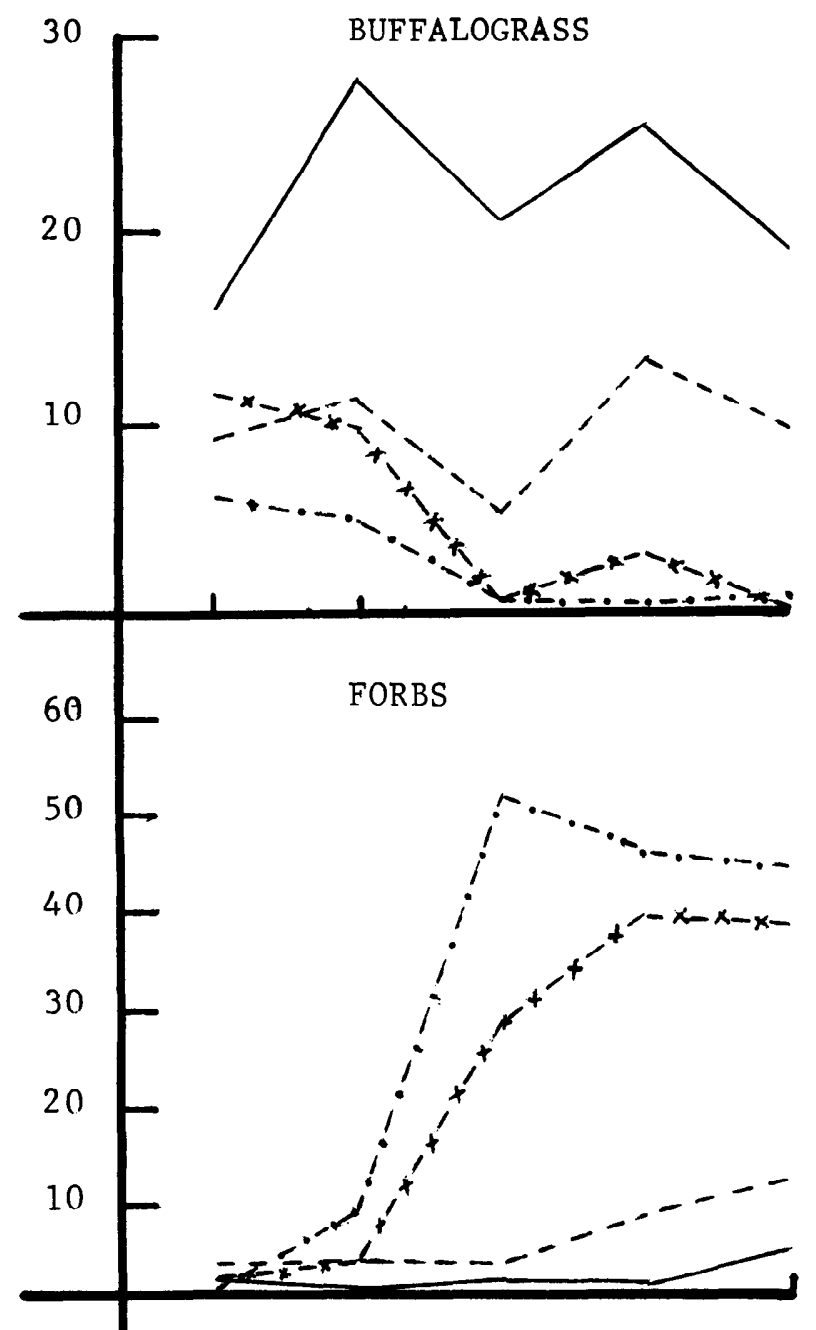

DRYLAND SEDGES
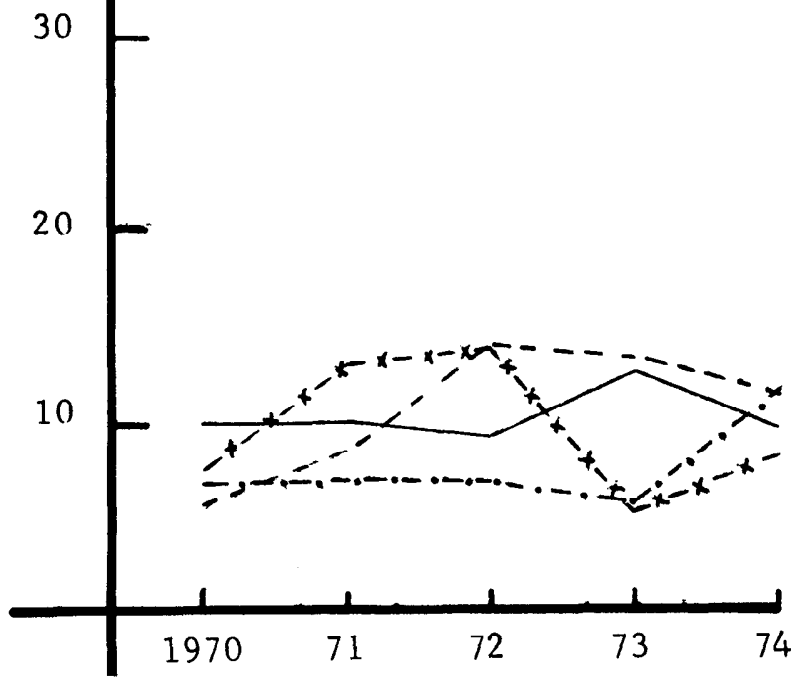

Fig. 1. Percentage composition by weight over a 5-year period from shortgrass rangeland fertilized with 0,150 , and $600 \mathrm{lb} / \mathrm{N} / \mathrm{acre}$ one time and $\mathrm{I50} \mathrm{lb}$ N/acre each year for 4 years (Archer Substation). 
the study, forbs were of little importance on all treatments. Yield of forbs, increased dramatically the next 2 years on the plots treated once with $600 \mathrm{lb}$ $\mathrm{N} /$ acre and the plots treated with $150 \mathrm{lb}$ N/acre annually for 4 years. Forb yield declined on these same high- $\mathrm{N}$ plots in 1974 because of limited precipitation in April and May. Even so, the forbs made up $45 \%$ of the total herbage on the plots treated once with $600 \mathrm{lb} \mathrm{N} /$ acre and $39 \%$ on the plots treated with $150 \mathrm{lb}$ $\mathrm{N} /$ acre annually for 4 years.

\section{Crude Protein}

Crude protein in the harvested western wheatgrass and blue grama from all treatments was significantly increased by the $N$ treatments. Significant differences between years in crude protein content of western wheatgrass and blue grama seem to be due to the amount and distribution of precipitation. Crude protein content was lowest in 1970 and highest in 1973; April-May-June precipitation in 1973 was less than half that luceived in 1970.

Average crude protein of western wheatgrass and blue grama was increased 24 and $37 \%$ over the check by $150 \mathrm{lb} \mathrm{N} /$ acre applied annually, and 58 and $72 \%$ by $600 \mathrm{lb} \mathrm{N} /$ acre applied once. Thus the two high $\mathrm{N}$ rates increased crude protein in the plant material, enhancing herbage quality.

\section{Composition}

Botanical composition of the vegetation on each plot was determined by weighing separated and direct herbage harvested from the subplots. Vegetative composition was influenced by $\mathrm{N}$ treatment and by the prevailing weather. The proportion of total herbage contributed by blue grama decreased and western wheatgrass increased on all treatments over the 5 -year period. On the plots treated once with $600 \mathrm{lb} \mathrm{N} /$ acre (Fig. 1) blue grama decreased from $68 \%$ the first year to $14 \%$ the fifth year; western wheatgrass increased from $13 \%$ the first year to $29 \%$ the last year of the study. Decreases in blue grama and increases in western wheatgrass were common to all treatments but were most drastic for the $600 \mathrm{lb} \mathrm{N} /$ acre treatments.

Forbs and annual grasses were of minor importance on the check and the plots treated once with $150 \mathrm{lb} \mathrm{N} /$ acre. However, they increased from $4 \%$ the first year to $44 \%$ the fifth year on plots treated with $150 \mathrm{lb}$ N/acre annually and from $6 \%$ to $45 \%$ on plots treated once with $600 \mathrm{lb} \mathrm{N} /$ acre.

Buffalograss on the two high $\mathrm{N}$ treatments decreased from an average of $9 \%$ the first year to a trace by the fifth year of the study. Apparently, buffalograss does not tolerate high $\mathrm{N}$ fertilization.

\section{Nitrate Concentration in the Soil}

Nitrate- $\mathrm{N}$ in the soil was determined all lik end of the study on September 10, 1974. Over the 5-year period (19701974) $\mathrm{NO}_{3}-\mathrm{N}$ moved downard in the soil profile, with the greatest accumulation from the high $\mathrm{N}$ rates in the 12- to 24-inch soil depth (Fig. 2). For the 150 lb N/acre applied each year for 4 years, accumulation of $\mathrm{NO}_{3}-\mathrm{N}$ in the 24- to 36-inch soil depth was less than half of that in the 12- to 24-inch soil depth. Twice as much $\mathrm{NO}_{3}-\mathrm{N}$ had accumulated in the 24- to 36-inch soil depth from the $600 \mathrm{lb}$ N/acre applied one time compared to $150 \mathrm{lb}$ N/acre applied annually for 4 years. Above-normal rains in late July (4.03 inches) and early September (4.48 inches) 1973 may have caused $\mathrm{NO}_{3}-\mathrm{N}$ to move deepe into the profile than is normal at thi: location.

\section{Root Biomass}

Total $\mathrm{N}$ in the root biomass did not differ significantly between treatments over the 5-year period at either the 0 - tc 6- or 6- to 12-inch soil depth. The average amounts of total $\mathrm{N}$ in the roo biomass for the four treatments wert 1.26 and $1.22 \%$ for the 0 - to 6 - and 6 - tc 12 -inch soil depths, respectively.

The average weight of the root bio. mass in the 0- to 6-inch soil depth was not significantly different betweer treatments. In the 6- to 12 -inch soi depth, significantly more root biomass was obtained from the $600 \mathrm{lb}$ N/acre treatment applicd once than from ths $150 \mathrm{lb} \mathrm{N} /$ acre treatment applied on time or annually for 4-years. There was no significant difference in the amoun of root biomass between the check anc the other three treatments. On a per acre basis, over all treatments, root biomas: averaged $21,000 \mathrm{lb} /$ acre in the 0 - to 6 . inch depth and 6,900 lb/acre in the 6 - tc
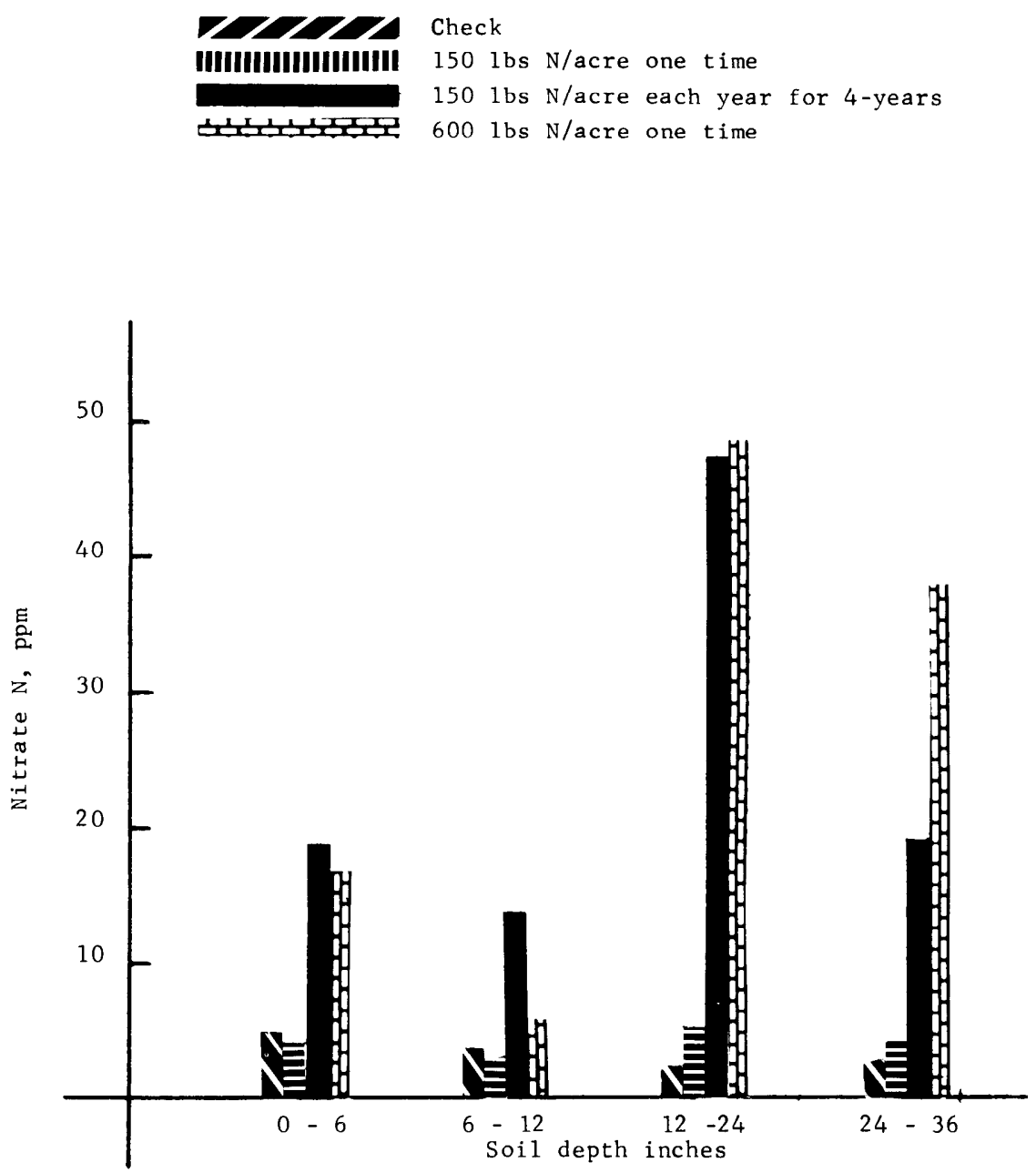

Fig. 2. Nitrate-N concentration in the soil profile (Archer Substation) September 1974. 
Table 2. Annual April through September, and April, May, and June precipitation (inches) for the 1970-1974 period, and the 54-year average at the Archer Substation, Wyo.

\begin{tabular}{|c|c|c|c|c|c|c|}
\hline Year & Annual & $\begin{array}{c}\text { April } \\
\text { through } \\
\text { September }\end{array}$ & April & May & June & Total \\
\hline 1970 & 15.4 & 11.3 & 1.5 & 2.7 & 3.2 & 7.3 \\
\hline 1971 & 13.1 & 9.9 & 2.9 & 2.7 & 1.0 & 6.7 \\
\hline 1972 & 14.8 & 11.9 & 1.4 & 1.4 & 4.0 & 6.8 \\
\hline 1973 & 18.5 & 11.5 & 1.8 & .6 & 1.1 & 3.6 \\
\hline 1974 & 11.6 & 7.7 & 1.2 & .3 & 3.1 & 4.6 \\
\hline 5-year avg. & 14.7 & 10.5 & 1.8 & 1.5 & 2.5 & 5.8 \\
\hline 54-year avg. & 14.7 & 11.4 & 1.5 & 2.5 & 2.5 & 6.6 \\
\hline
\end{tabular}

12-inch soil depth. This amount of root material represents an average of $265 \mathrm{lb}$ $\mathrm{N} /$ acre in the 0 - to 6-inch soil depth and $84 \mathrm{lb} \mathrm{N} /$ acre in the 6- to 12-inch soil depth. Power and Alessi (1971) found $23,800 \mathrm{lb} /$ acre of root material on a loamy range site in the top 12-inches of soil, while Wight (1976) found 18,000 $\mathrm{lb} / \mathrm{acre}$ on a sandy upland range site in Montana.

\section{Precipitation and Evapotranspiration}

Distributions and amounts of annual, seasonal, and April-May-June precipitations were erratic and influenced the herbage yield and vegetative composition (Table 2). The April-MayJune precipitation was $12 \%$ above the 54-year average in 1970, but it was $45 \%$ below the long-time average in 1973. Precipitation during April and May 1972, was light and of little value for plant growth, whereas the June precipitation of 4.03 inches was responsible for most of the plant growth. Annual precipitation was highest in 1973, with 4.48 inches of rain received during September. Most of the winter precipitation was received during October, November, and March and generally contributed little to the soil water except where snow was trapped or drifted. The winter of 1971-1972 was dry and open, with high winds that dessicated the surface soils. Late spring snowstorms in 1973 and 1974, accompanied by high winds that caused irregular drifting, resulted in variable amounts of water entering the soil.

Differences between average soil water content in April and again in either August or September plus the precipitation from events greater than 0.10 inch were considered evapotranspiration. Average evapotranspiration for 1971 through 1974 was 9.1, 9.3, 8.7 , and 9.1 inches for the check, 150 lb N/acre applied one time, $150 \mathrm{lb}$ $\mathrm{N} /$ acre applied annually for 4 years and $600 \mathrm{lb}$ N/acre applied one time. Thus the overall average evapotanspiration during the growing season was 9.0 inches. The most soil water was available and used in all evapotranspiration during 1973, and the least, in 1971. By early fall nearly all the water in the upper 2 feet of soil was exhausted. Rains in late August and September were of little value for plant growth but did aid in recharging the soil profile.

Water-efficiency for each treatment was determined by dividing total water used into average total herbage produced. The high $\mathrm{N}$-plots had the highest water-use efficiency, mostly because of the greater amount of annual forbs. However, water-use efficiency dropped sharply if only the total grass and sedges were considered. Wateruse efficiency was highest for plots. receiving $150 \mathrm{lb}$ N/acre each year for 4 years and lowest for the check.

\section{Literature Cited}

Choriki, R. T., D. E. Ryerson, A. L. Dubbs, and Jack Taylor. 1968. Rates and spacing of fertilizer on improvement of yield, species, and nutrients absorption of mixed prairie vegetation. Agron. Abst., Amer. Soc. Agron. p. 100 .

Dwyer, Don D. 1971. Nitrogen fertilization of blue grama rangeland in the foothills of SouthCentral New Mexico. New Mexico State Agr. Exp. Sta. Bull. 585. p. 1-8.

Ford, R. H., and F. H. Siddoway. 1971. Range fertilization studies on upland till plains of Northeastern Montana. Proc. 22nd Annu. Fert. Confer. of the Pac. Univ. p. 55-64.

Houston, W. R., and D. N. Hyder. 1975. Ecological effects and fate of $\mathrm{N}$, following massive $\mathrm{N}$, fertilization of mixed-grass plains. J. Range Manage. 28:56-60.

Houston, W. R., and D. H. Van Der Sluijs. 1973. Foliar-applied urea and ammonium nitrate fertilizer on shortgrass range. J. Range Manage. 26:360-364.

Hyder, D. N., and R. E. Bement. 1972. Controlling red threeawn on abandoned cropland with ammonium nitrate. J. Range Manage. 25:443-446.

Johnston, A., S. Smoliak, A. D. Smith, and L. E. Lutwick. 1967. Improvement of southeastern Alberta range with fertilizers. Can. J. Plant Sci. 47:671-678.
Johnston, A., A. D. Smith, L. E. Lutwick, and S. Smoliak. 1968. Fertilizer response of native and seeded range. Can. J. Plant Sci. 48:467-472.

Lorenz, J. Russell, and George A. Rogler. 1973. Interaction of fertility level with harvest date and frequency on production of a mixed prairie. J. Range Manage. 26:50-54.

Power, J. F. 1970. Leaching of nitrate nitrogen under dryland agriculture in the Northem Great Plains. Cornell Univ. Press, New York. p. 111-122.

Power, J. F., and J. Alessi. 1971. Nitrogen fertilization of semiarid grasslands: Plant growth and soil mineral N, levels. Agron. J. 63:277-280.

Power, J. F. 1972. Fate of fertilizer nitrogen applied to a Northern Great Plains ecosystem. J. Range Manage. 25:367-371.

Rauzi, Frank, Robert L. Lang, and L. I. Painter. 1968. Effects of nitrogen fertilization on native rangeland. J. Range Manage. 21: 287-291.

Wight, J. Ross. 1975. A summary of range fertilization on research conducted by the Northern Plains Soil and Water Research Center. Proc. Range Symp. Mont. Agr. Exp. Sta. Res. Rep. 70. p. 6.

\section{G56}
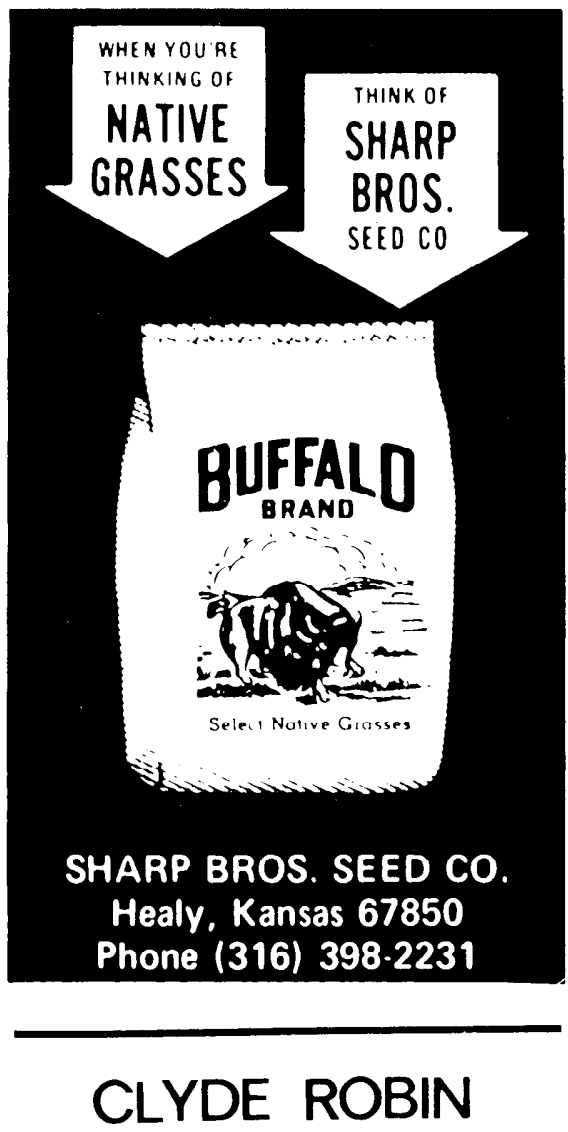

\section{NATIVE SEEDS}

Castro Valley, California 94546 